\title{
Critical strategic analysis forecast of the oil and gas business unit of General Electric Company: A conceptual review
}

\author{
Adeyemi Z. Oshilalu* and Yolandie C. Baldie \\ Department of Business Administration, Faculty of Business and Society, University of South Wales, United Kingdom \\ ${ }^{*}$ Corresponding author. Email: adeyemioshilalu@gmail.com \\ Copyright $@ 2021$ Oshilalu and Baldie. This article remains permanently open access under the terms of the Creative Commons Attribution License \\ $\underline{4.0}$, which permits unrestricted use, distribution, and reproduction in any medium, provided the original work is properly cited.
}

16th October, 2020; Accepted 24th December, 2020

\begin{abstract}
The General Electric Company (GE) is considerably assessed as one of the world's most successful corporations in the 20th Century. GE is a huge multinational conglomerate with one of the most highly innovative business units/divisions in the world. Due to the vast majority of GE's products and services, a critical strategic analysis forecast of one of the conglomerate's eight business units - Oil and Gas is presented for a conceptual review. The paper details how these Strategic Business Units (SBUs) explored the efficiency and market focus of their business portfolio through diversification, innovation, and acquisition. Resource allocation and value chain analysis of the SBU was conducted to determine the certainty of the company's competitive edge. The portfolio of the SBU; oilfield services, oilfield equipment, turbomachinery, and process \& digital solutions were reviewed using the Boston consulting group (BCG) matrix while the Ansoff matrix was employed to analyze and predict the company for sustainable future growth and divestment. In 2017, the synergy between these SBU and Baker Hughes to deliver a full-stream integrated oilfield portfolio revealed a strong and enhanced competitive advantage of the SBU across the global oil and gas industry, however, the analysis of the company shows that the SBU still experiences underperformance in the stock market.
\end{abstract}

Keywords: Acquisition, competitive advantage, diversification, full-stream, merger, oil and gas, portfolio, strategic business unit.

\section{INTRODUCTION}

General Electric company is one of the largest American multinational firms in the world, comprising of many strategic business units ranging from oil and gas, lighting, aviation, transportation, financial services, power and water, renewable energy to healthcare. Each unit acts as an independent business in all major respects, especially as it relates to the formulation of their strategic plans as well as their marketing strategy (Gryta and Mann, 2018; Sammut-Bonnici and Mc Gee, 2015). GE has continued to remain relevant across its SBUs to create a strong competitive edge (Pratap, 2018). Many market researchers argued that General Electric has been able to sustain these competitive advantages over the years because it allows each business unit to act as an independent business entity that particularly understands the needs and desires of their respective customers
(Kenny, 2012).

It may seem rather challenging to strategically analyze all GE's strategic business units at once, hence, the authors narrowed the focus of the article on GE Oil and Gas and how this SBU managed the efficiency and market focus of their business portfolio through diversification, innovation, and acquisition. According to Sammut-Bonnici and Mc Gee (2015), based on the degree of freedom granted by the management of a corporation, individual SBUs or divisions may share the parent organization's corporate identity or develop its own brand identity. GE acquired Baker Hughes and merged both companies to create a world-class company, Baker Hughes, a General Electric Co (BHGE). BHGE employed a unique blend of equipment capabilities and service delivery within GE's oil and gas SBU to create a competitive edge. 


\section{Objectives}

An overview of GE's oil and gas SBU is conducted to explore its position using economic tools and techniques. Simultaneously, this overview explores how the SBU utilizes scarce economic resources for the growth and development of the SBU as an operating entity of the conglomerate. The objectives of the research are enumerated as follow:

- To review the Strategic Position of the company,

- To evaluate the SBU's resources and Value System, and Product/Portfolio Mix,

- To determine the key future directions of the SBU for the strategic growth of the conglomerate.

\section{Methodology}

This report takes its references mostly from financial market articles and surveys, a few academic sources; as well as the corresponding author's personal experience having worked within the oil and gas industry for almost 15 years. The selected SBU is appraised through the development of resource allocation, Value Chain Analysis, and The BCG Matrix/Ansoff Matrix.

\section{STRATEGIC POSITION OF GENERAL ELECTRIC}

General Electric used to be categorized as the king of the stock market and was rated as the world's most valuable company at $\$ 380$ billion in the year 2000 (Pratap, 2018). For over 130 years, the company has continued to maintain a rich historical legacy with its business model showing remarkable consistency particularly from 1992 to 2001 with a double-digit level of growth and earnings of 150 to $200 \%$ GDP growth (Market is Open, 2019). During these years, GE has undergone diverse developmental changes through which its strategic capabilities were effectively maximized, and its diversified portfolios enhanced the company's growth (Bucifal, 2009). Although the strategic position of GE was strengthened through several mergers, acquisitions, and strategic alliances in the global marketplace by demonstrating better service delivery even to its peripheral divisions, the management of the company, however, reported a wide range of public perceptions of GE's complexity due to these acquisitions (Colvin, 2006; Pratap, 2018). Consequently, the need for management to develop new strategies to re-evaluate and redefine all its SBUs to achieve organic growth rather than growth through mergers and acquisitions (Lowder, 2006; Stewart, 2006). In the conglomerate's transparent quest for natural and organic growth, the company disposed-of some weak divisions in the year 2000 (Pratap, 2018). In GE's 2017 Annual report, the company shows strong financial results in revenue within the oil and gas segment as well as the aviation, renewable energy, and healthcare. This does not exclude the decline in performance in some of its SBUs due to several growth challenges, low quality, and underperforming technology. For instance, GE lighting experienced a wide variety of global competitors in LED lighting innovations, hence a decline in sales and margins of GE's traditional lighting products since many point solution companies now explore energy-efficient lighting products. To enhance this SBU for instance, GE must invest in LED conversion products for both consumer and commercial markets to boost significant growth potential (GE Annual report, 2017). However, the overall financial performance still looked good and the brand has continued to position itself to still be able to sustain competitive pressure despite present the decline in the stock market.

\section{General Electric Oil and Gas Business Division: Relative and strategic position and valuation}

GE Oil and Gas is one of the divisions of General Electric whose investments lie within the petroleum industry. The division is now regarded as Baker Hughes, a General Electric Co (BHGE) after its merger in July 2017. Before the merger, the intent of the leadership of the conglomerate to consolidate the growth in the oil and gas SBU of General Electric required the development of an acquisition strategy that would add value to Baker Hughes through full-stream innovation, technology leadership, and operations optimization in the global oil and gas sector (Durant, 2019). Globally, there was non-existence of an establishment that could provide a full-stream portfolio in the oil and gas industry. GE Oil and Gas SBU comprising of five major business segments; surface, subsea systems and drilling, turbomachinery solutions, downstream technology, and digital solutions will not provide an end-toend solution except with a combination of Baker Hughes' five major business segments; advanced drilling services, logging and evaluation, completions systems, production optimization, and industrial services. This strong complementary portfolio gives BHGE the ability to go fullstream bringing about strong competitive scope and value proposition across the industry. Upon the acquisition with a $62.5 \%$ stake, the merger made BHGE the world's second-largest oilfield service provider by revenue after Schlumberger, thus having an estimated revenue of $\$ 24$ billion (GE M\&A Presentation, 2016). This robust synergy gives BHGE the platform to enable digital capabilities and make the SBU the world's first complete full-stream integrated oilfield portfolio. The management of GE haven spotted Baker Hughes sharing the same customers; ExxonMobil, Chevron, Eni, Saudi Aramco, bp, Total, Shell, etc for their respective portfolios but each of them could not provide end-to-end integrated customer solutions. Thus, the new BHGE with its consolidated staff strength and long-term experience will have the capacity to enhance productivity across the oil and gas value chain as full-stream. This means that BHGE can extract, transport, and refine hydrocarbons for their clients safely, efficiently, and economically. Considering GE's strength in digital 
capacities that allows upstream oil production at the lowest cost per barrel, it became easy for BHGE to promote its businesses through innovative ideas (Reuters, 2017). However, will this acquisition produce positive effects in the long term? Since 2018 after the integration of Baker Hughes with GE, BHGE appears to be poorly executed. There seems to be no clear indication of whether Baker Hughes has the necessary managerial power to influence its strategic perspective with only 4 representations out of 14 executive members and 4 out of 9 board members (Durant, 2019). Baker Hughes as the more economically viable entity before being acquired should not have been majorly dominated by GE personnel at the BHGE executive board if GE professionals do not have the necessary technical expertise or experience to guide the synergy. In the long run, this approach may likely contribute to the erosion of value for shareholders. Due to volatility in crude oil prices in recent years, BHGE decided to adopt three-pillar corporate strategies to sustain customers who are now seeking innovative solutions that will be result-oriented while leveraging on economies of scale as well as reducing carbon impact (BHGE, 2018). This differentiation strategy combines with improvement in productivity and industrial yield at a reduced cost of operation has resulted in positioning BHGE as one of the most highly valued oilfield services and equipment companies. See data from Table 1 with a relative comparison of the world's major Oilfield Service and Equipment Companies corroborating these claims.

Despite BHGE's performance among its rivals, when compared with the world's major oilfield service and equipment companies, it is however shocking to see the company's stock price significantly underperforming. Although the downside protection afforded by its lessvolatile digital solutions and turbomachinery and process solutions segments may be viewed to enhance its share price performance as seen in Table 1. Perceived inferior product and service portfolio as well as management team lacking the necessary skill set to guide the company, and turmoil from the acquisition, in reality, has continued to represent some level of underperformance as projected in Figure 1. Hence, in 2018 General Electric announced it plans to divest its investment in BHGE by reducing its ownership stake from $62.5 \%$ to $50.4 \%$ (Helman, 2020). Again, in September 2019, GE continued divestment of the company's holding from $50.4 \%$ to $38.4 \%$ to raise $\$ 2.7$ billion in the process to pay off some of its corporate debt load (Durant, 2019; Reuters, 2019). As such, the management consideration regarding exit options may help dismantle the company's robust empire, thereby leading to feasible profitability.

\section{RESOURCES AND VALUE SYSTEM ANALYSIS}

According to Grant (1991), capabilities refer to "the capacity of a set of resources to integratively perform a task or activity" whereas Henry (2008) views capabilities as "the attributes that firms require to be able to compete in the marketplace". With these definitions, we can safely refer to capabilities as a configuration of resources and processes that allow organizations/firms to be competitive. In this section, the strategic capabilities of General Electric Oil and Gas SBU are analyzed. A value chain will be constructed to outline the strategic capabilities of BHGE, which will then be analyzed using a BCG matrix framework.

\section{BHGE resources and capabilities}

The certainty of determining if GE provides a competitive advantage requires identifying the resources of the company first. Upon evaluating these resources, it makes it easier to define the main capabilities of BHGE, beginning from the core ones, and finishing with the distinctive ones. The analysis will be broken down in Table 2 covering all required information that will enable us to uncover the competitive advantage of BHGE.

The Table 2 depicts BHGE as a robust company structure that has the capability to provide full stream technology to its customers and with the introduction of new technologies to the oil and gas industry using consolidated human resources experienced. Overall, it is believed that costs and benefit advantages depend on different capabilities of the company to yield a low-cost product or high-value product (Fearne et al., 2012). Although despite the robust resources and capabilities of the SBU, BHGE seems to struggle among its peers. As such, resources and capabilities alone do not assure a firm's capabilities to attain sustained competitive advantage, but continuous re-evaluation and reexamination of the company's sustainable business strategies. Upon evaluating the capabilities of BHGE by resource-based analysis, some researchers insist that this examination is only focused on a firm internal perspective and this does not give a full view of the industry being analyzed (Priem and Butler, 2001). Priem and Butler argue that "saying a business holds a competitive advantage due to superior resources or being better at some things is not helpful unless it is possible to be specific about what resources are important, why and how they can be managed". BHGE should rejig the structure of their resource and capabilities framework to identify, protect, and uncover certain components of their resources that need to be improved to ensure long-term competitive advantage. In this case, the leadership should either be trained with a specific skill set required to manage the portfolio or replaced with more technical executives.

\section{BHGE value system}

Krajewski et al. (2007) present value chain as "the internal linkages between a firm's core process, its supporting process, and its external linkages with the processes of its 
Table 1. Relative comparison of world major Oilfield Service companies (Durant, 2019)

\begin{tabular}{lccc}
\hline Oilfield Service companies & $\begin{array}{c}\text { Price to Earnings } \\
\text { Ratio (P/E) }\end{array}$ & $\begin{array}{c}\text { Price to Book } \\
\text { Ratio (P/B) }\end{array}$ & $\begin{array}{c}\text { Enterprise value- } \\
\text { to-sales (EV/S) }\end{array}$ \\
\hline BHGE & 70.7 & 0.70 & 1.46 \\
Slumberger & 24.3 & 1.75 & 1.79 \\
Haliburton & 13.2 & 1.32 & 1.14 \\
NOV & - & 1.05 & 1.25 \\
TechnipFMC & - & 1.09 & 0.90 \\
\hline
\end{tabular}

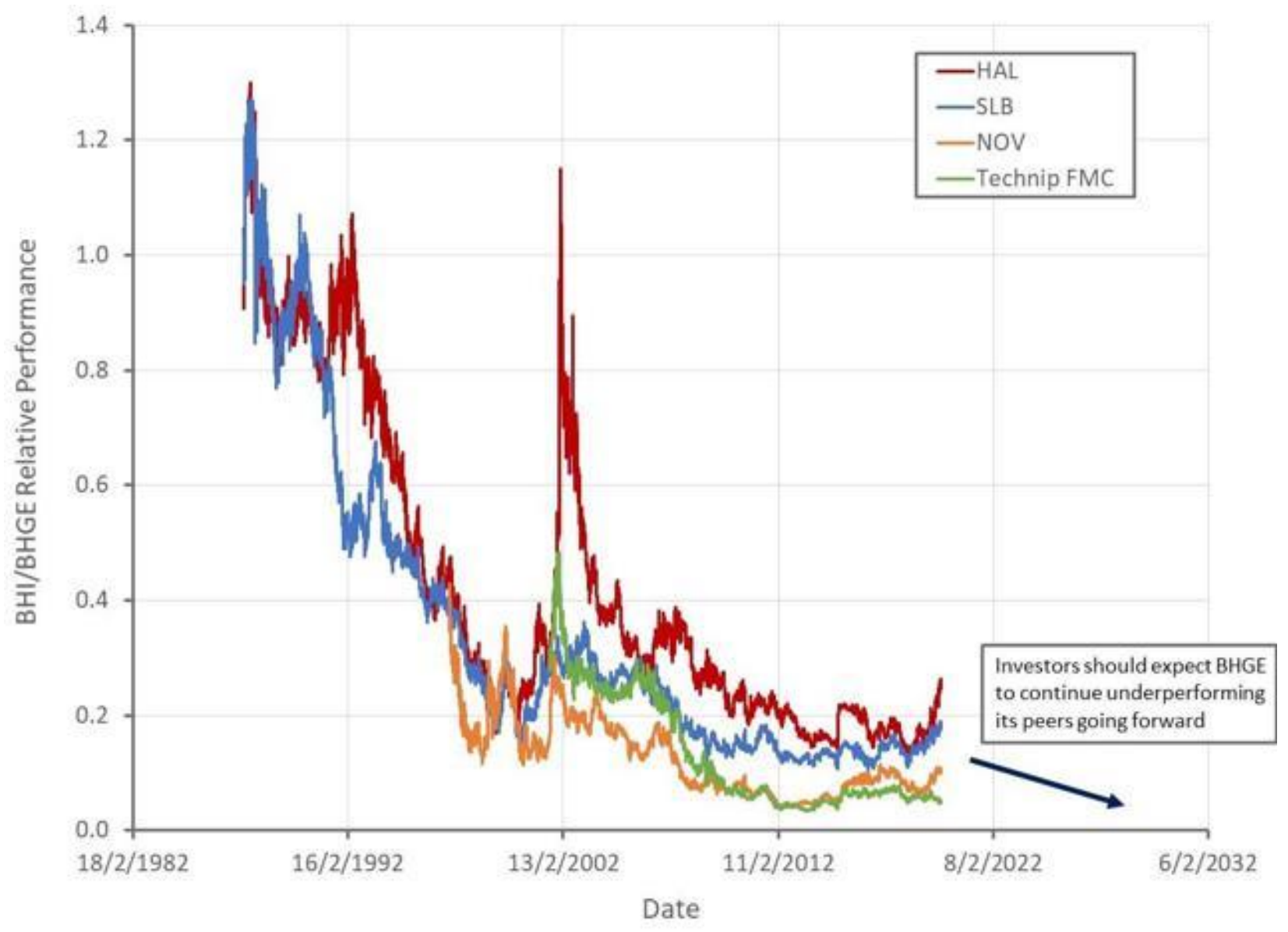

Figure 1. BHGE relative stock market performance (Durant, 2019).

customers and suppliers". While Fearne et al. (2012) describe a chain as a series of actions and activities that aim to add value. To understand how BHGE generates value for its customers, it is important to determine and analyze its value chain system. By doing so, business operations optimization was conducted using Porter's Value chain model (Figure 2).

Porter's value chain model is broken down to identify the resources and competencies of the company as shown in Table 3. Activities of the exploration and extraction have to do with exploring designated areas to ascertain the presence of crude (Cairn, 2015). These activities enable
BHGE to add value to the customers who are in search of identifying amounts of gas and oil reserves, which can thereafter be extracted and sent forth for refining. GE prides itself on its oil and gas industry on deep-rooted Research and Development (R\&D) expertise, a key component that brings forth commercial innovations for its operational activities. These hydrocarbons, upon being refined to several usages, the value created is the raw materials produced into a variety of products such as petrol - premium motor spirit (PMS), Diesel - Automotive Gas Oil (AGO), cooking gas - liquified petroleum gas (LPG), Aviation Turbine Kerosene (ATK), etc. The receipt of these 
Table 2. BHGE resource allocation

\begin{tabular}{|c|c|c|c|}
\hline \multicolumn{2}{|c|}{ Type/resources } & \multirow[b]{2}{*}{$\begin{array}{l}\text { Characteristics } \\
\text { - } \quad \text { Revenue from Acquisition: The new } \\
\text { company, BHGE has a cost savings of } \\
\$ 1.2 \text { billion by } 2020 \text { and } \$ 400 \text { million in } \\
\text { revenue (Durant, } 2019 \text { ). } \\
\text { - Funding from Parent Company: GE can } \\
\text { use their SBU, GE Capital to issue } \\
\text { advanced capital credit to invest and } \\
\text { grow its brand. }\end{array}$} & \multirow[b]{2}{*}{$\begin{array}{l}\text { Indicators } \\
\text { - Cash Flow: Annual } \\
\text { forecasted revenue of } \$ 22 \\
\text { billion with an operating } \\
\text { income of } \$ 1 \text { billion. } \\
\text { - Leasing/Renting: Cashflow } \\
\text { from heavy-duty equipment } \\
\text { leasing to some sub- } \\
\text { contractors who do not have } \\
\text { the capital to procure them. }\end{array}$} \\
\hline & Financial & & \\
\hline Tangible & Physical & $\begin{array}{l}\text { Equipment: All existing equipment } \\
\text { owned or acquired by GE, for instance, } \\
\text { some gas turbines and compression } \\
\text { pump acquired from Nuovo Pignone in } \\
\text { 1994, equipment from Lufkin in } 2013 \text {, } \\
\text { and all Baker Hughes machinery in } \\
2017 \text { as well as turbomachinery, } \\
\text { subsea drilling equipment, etc. owned } \\
\text { by GE. } \\
\text { Land: All landed properties acquired or } \\
\text { owned within all BHGE operations } \\
\text { across } 120 \text { countries } \\
\text { Buildings: Similarly, all offices, plants, } \\
\text { workshop, or fabrication yard }\end{array}$ & $\begin{array}{l}\text { Equipment Certifications: } \\
\text { Updated equipment } \\
\text { certifications and } \\
\text { recertification before putting } \\
\text { them to use. } \\
\text { - The layout of Fabrication } \\
\text { Yard, workshop, or plants. }\end{array}$ \\
\hline \multirow[t]{2}{*}{ Intangible } & Technology & $\begin{array}{ll}\text { - } & \text { Digital Solutions } \\
\text { - } & \text { Downstream Technology } \\
\text { - } & \text { Turbomachinery Solutions } \\
\text { - } & \text { Completions System } \\
\text { - } & \text { Industrial Services } \\
\text { - } & \text { Production Optimization } \\
\text { - } & \text { Advanced Drilling Services } \\
\text { - } & \text { Subsea systems and Drilling }\end{array}$ & $\begin{array}{ll}\text { - } & \text { R\&D Staff } \\
\text { - } & \text { Turnaround time } \\
\text { - } & \text { Production time }\end{array}$ \\
\hline & Reputation & $\begin{array}{l}\text { - Strong alliance for integrated solutions } \\
\text { - } \quad \text { Collaborative process } \\
\text { - } \quad \text { Political/ Government support }\end{array}$ & $\begin{array}{l}\text { - } \quad \text { Customer Satisfaction } \\
\text { - } \quad \text { Public Surveys }\end{array}$ \\
\hline Human & & $\begin{array}{l}\text { - Highly Skilled Employees: BHGE has a } \\
\text { combined employee above 70,000 } \\
\text { which is strongly viewed as their most } \\
\text { valuable asset (Durant, 2019). } \\
\text { - } \quad \text { Adaptability } \\
\text { - } \quad \text { Commitment }\end{array}$ & $\begin{array}{l}\text { - } \quad \text { Employee Qualifications } \\
\text { - } \quad \text { Pay rates }\end{array}$ \\
\hline
\end{tabular}

raw materials for production are likened to the inbound logistics (Crocker et al., 2012).

Also, GE Logistics Execution Center supports the industry with outbound logistics and freight management with their access to Oracle Transportation Management (OTM) tools for distribution to tank farms (General Electric, 2018). This adds value as it ensures the client's stations always have plenty of products to sell. GE's proven industry expertise in advanced digital and analytical tools and service places them at a leading portfolio of technological advantage, enabling maximization of value across all assets (BHGE Annual Report, 2018).
Furthermore, good service delivery is a crucial selling point for the marketing team, enabling BHGE prides itself as a leading industrial player in the oil and gas sector because of the quality services and support rendered to its customers. Overall, BHGE developed four resource highlights to sustain a competitive edge in the oil and gas value chain:

- To become the best partner to oil and gas customers by offering full-stream solutions based on complementary equipment services technology from GE and Baker Hughes (Figure 3). 




Figure 2. Value chain model.

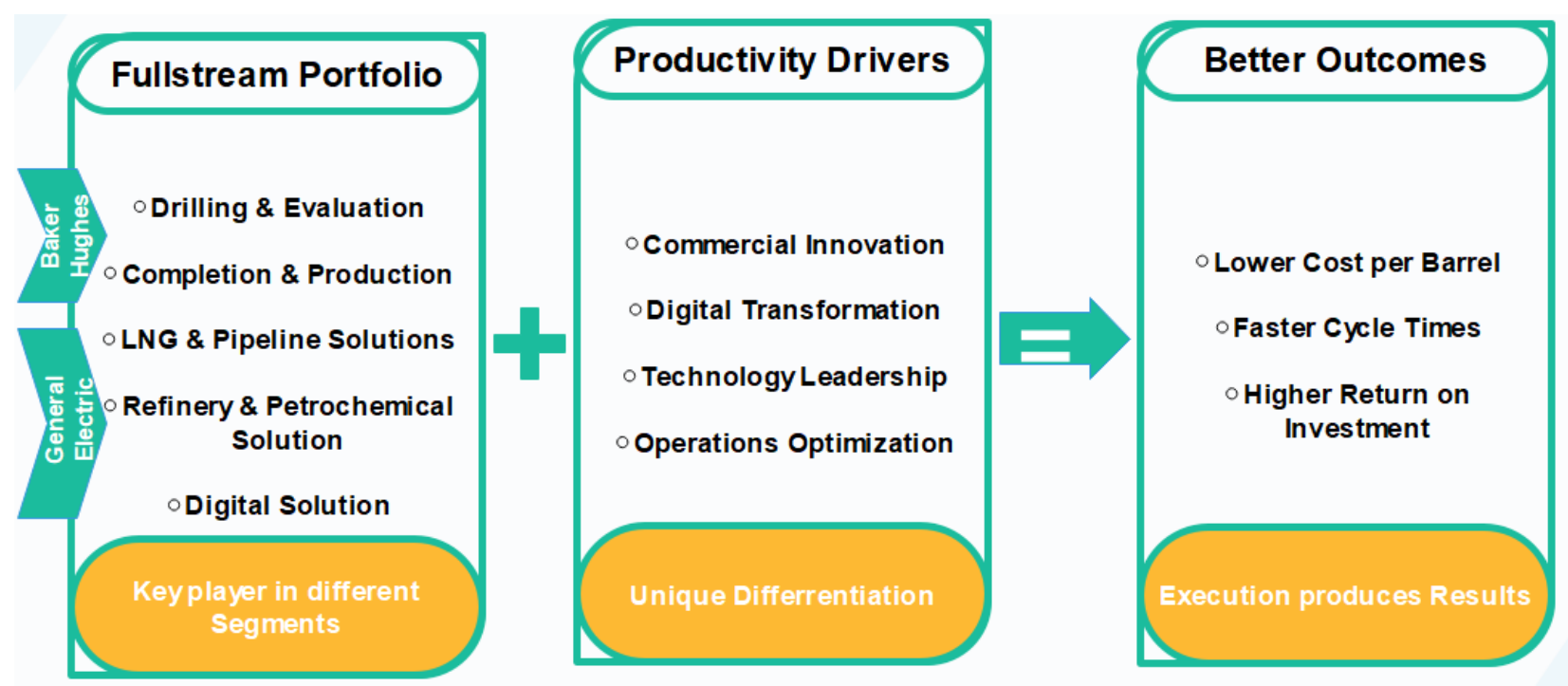

Figure 3. The rationale behind enhanced productivity.

- To enhance more innovative market solutions faster and more cost-effectively with Baker Hughes' leading products and services and GE Oil \& Gas's highly differentiated manufacturing capabilities.

- To combine Baker Hughes' domain expertise, technology, and culture of innovation with GE Store and GE's industry-leading Digital Platform to be the best-in-class physical plus digital technology.

- To position itself to weather short-term volatility and participate in quick industry recovery to create value for customers and shareholders (GE - M\&A Presentation, 2016; Carhcart and Kania, 2017).

Durant (2019) came up with an argument that though operating companies may seem to be pushing for integrated service offerings to reduce costs and the complexity of their operations, there are, however, only a handful of projects managed by national oil companies where there is any interest in integrating services across upstream, midstream and downstream.

\section{GENERAL ELECTRIC'S PRODUCT/PORTFOLIO MIX WITHIN THE BHGE}

It is the prerogative of all firms to view their business units as a portfolio. As such, while some products should receive investment because they are cash-generating and necessitating these investments required keeping them healthy and to exploit growth opportunities, others simply need investment because they are the future stars of the company, even though they now have more potential than 
Table 3. BHGE value chain analysis.

\begin{tabular}{|c|c|}
\hline Value chain analysis & Description of activities \\
\hline \multicolumn{2}{|l|}{ Primary activities } \\
\hline Exploration \& Extraction & $\begin{array}{l}\text { - Facilities Planning } \\
\text { - Supply Schedules }\end{array}$ \\
\hline $\begin{array}{l}\text { Operations (Refining \& } \\
\text { Production) }\end{array}$ & $\begin{array}{ll}\text { - } & \text { Maintenance } \\
\text { - } & \text { Production } \\
\text { - } & \text { Quality Control }\end{array}$ \\
\hline $\begin{array}{l}\text { Distribution to Station } \\
\text { (Tank Farms) }\end{array}$ & $\begin{array}{l}\text { - Warehousing } \\
\text { - Invoicing }\end{array}$ \\
\hline Marketing \& Sales & $\begin{array}{ll}\text { - } & \text { Market research } \\
\text { - } & \text { Client Management }\end{array}$ \\
\hline After Sales Services & $\begin{array}{ll}\text { - Facilities maintenance } \\
\text { - Warranty }\end{array}$ \\
\hline Support activities & $\begin{array}{ll}\text { - } & \text { Regulatory Compliance } \\
\text { - } & \text { New Infrastructures } \\
\text { - } & \text { Financial Strength }\end{array}$ \\
\hline Firm Infrastructure & $\begin{array}{l}\text { - } \quad \text { Skilled Employees } \\
\text { - } \quad \text { Age-Long Brand } \\
\text { - } \quad \text { Limited Service Differentiation }\end{array}$ \\
\hline $\begin{array}{l}\text { Human Resource } \\
\text { Management }\end{array}$ & $\begin{array}{l}\text { - Operational Safety training such as basic offshore safety induction and emergency training } \\
\text { (BOSIET), Offshore Safety Permit (OSP), etc. } \\
\text { - Access to OTM } \\
\text { - Developmental training to employees such as Business Development Training, Analyst } \\
\text { Training, etc. }\end{array}$ \\
\hline $\begin{array}{l}\text { Product \& Technology } \\
\text { Development }\end{array}$ & $\begin{array}{ll}\text { - } & \text { Production Engineering } \\
\text { - } & \text { Performance Analysis } \\
\text { - } & \text { Research \& Development }\end{array}$ \\
\hline Procurement & $\begin{array}{l}\text { - } \quad \text { Supply management } \\
\text { - } \quad \text { Specifications } \\
\text { - } \quad \text { Sub-contracting } \\
\text { - } \quad \text { Funding }\end{array}$ \\
\hline
\end{tabular}

sales and profits as reflected in Figure 4. The products/portfolio of BHGE is classified into four divisions; oilfield services, oilfield equipment, turbomachinery, and process solutions, and digital solutions each with basic functions summarized in Table 4.

For the segments of General Electric Oil and Gas (BHGE), we would develop an applicable BCG matrix based on a conscious examination of market reports and survey data from Table 4. According to BHGE's 2017 financial report, a decrease in revenues generated from turbomachinery and process solutions was recorded as $14 \%$ as compared to the 2016 report (BHGE Annual Report, 2017). This was attributed to the high supply on the market and the increase in demand for petrochemicals and refinery utilization. However, the segmented and diverse nature of BHGE was able to absorb the effects of 


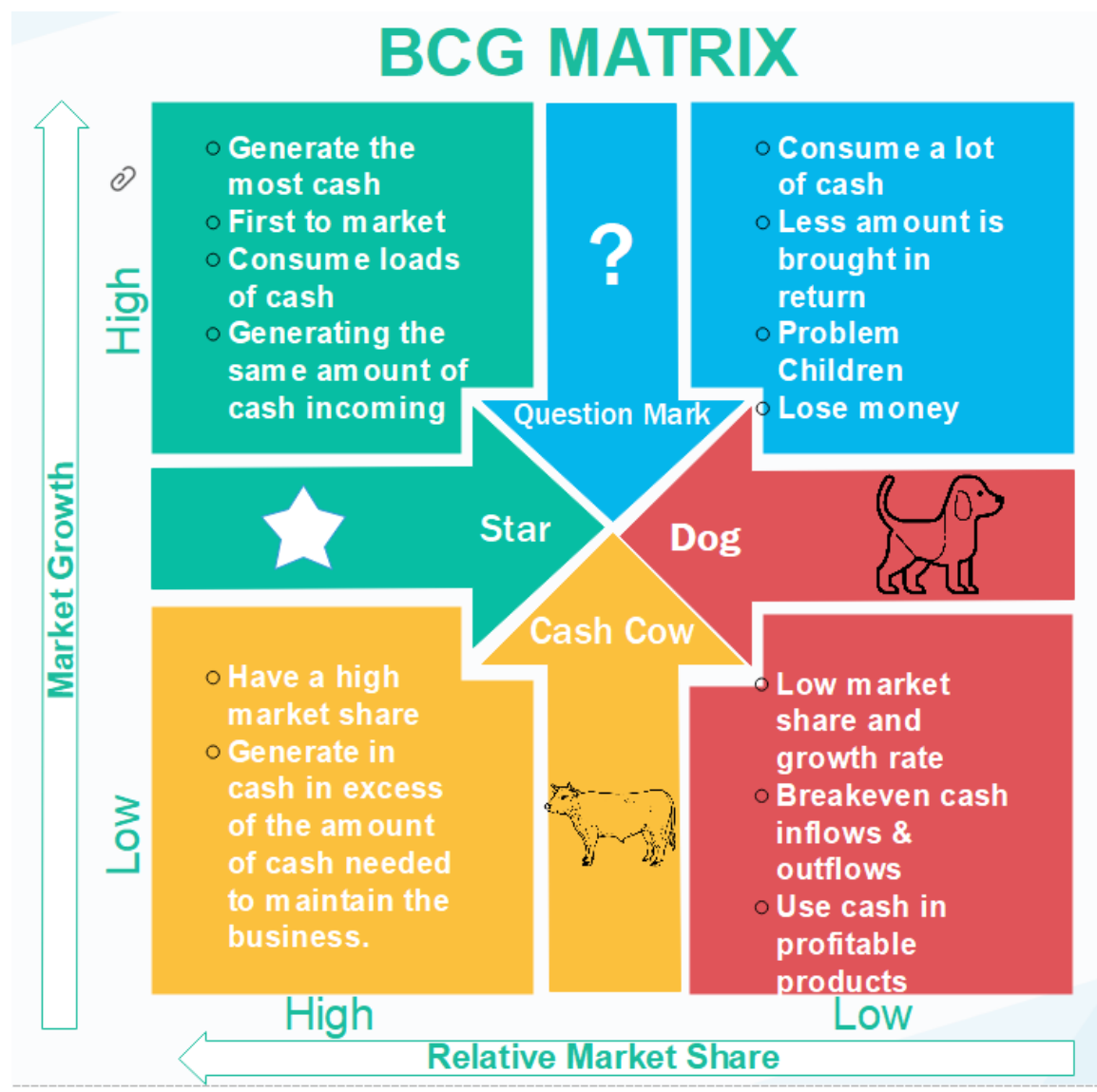

Figure 4. BCG Matrix.

Table 4. BHGE segment revenue and volatility of profit margins (Durant, 2019).

\begin{tabular}{|c|c|c|c|}
\hline Segment/Divisions & Services & Revenue & Profit margin volatility \\
\hline Oilfield Services & $\begin{array}{l}\text { Global presence in well construction and } \\
\text { production }\end{array}$ & $50.9 \%$ & $14.1 \%$ \\
\hline Oilfield Equipment & $\begin{array}{l}\text { The broad portfolio of subsea technology } \\
\text { offerings and solutions }\end{array}$ & $11.4 \%$ & $11.9 \%$ \\
\hline Digital Solutions & $\begin{array}{l}\text { Sensing and measurement technology } \\
\text { and software }\end{array}$ & $11.4 \%$ & $1.4 \%$ \\
\hline Turbomachinery and Process Solutions & LNG and upstream production & $26.3 \%$ & $4.9 \%$ \\
\hline
\end{tabular}

the turbomachinery and process solutions loss. This analysis justified the reason for placing turbomachinery solutions under grid 3 of the BCG matrix.

Reuters (2018) however reported an increase in the areas of controlled business lines and sensor-based measurement increased by $4 \%$ in 2017 , as well as a significant increase in operating income of turbomachinery and process solutions from \$157 million in Quarter 42017 to $\$ 257$ million in Quarter 4 2018. The increase in the demand for digital solutions provides BHGE the solution to the turbomachinery and process solutions problem in its anticipated growth in LNG production. As such, digital solutions can safely be placed under grid 2. BHGE's subsea systems and drillings (SS\&D) under the Oilfield Equipment portfolio were seen to experience a decrease in revenue by $-21 \%$ and low market share as recorded in the BHGE 2017 annual financial report, indicating very low operating income of $\$ 1$ million, \$6 million and $\$ 12$ million in Quarter 4 2017, Quarter 32018 and Quarter 42018 respectively, hence spotted on grid 4 of the BCG matrix. Oilfield Services, the downstream technology solutions of the BHGE segment recorded the highest growth in 2017, at 10\% (BHGE annual report 2017; Motley Fool, 2019). This segment will offer a more attractive position especially in production chemicals and artificial lift, which could perform strongly as operating companies are now 


\section{GE OIL AND GAS BUSINESS UNIT BCG}

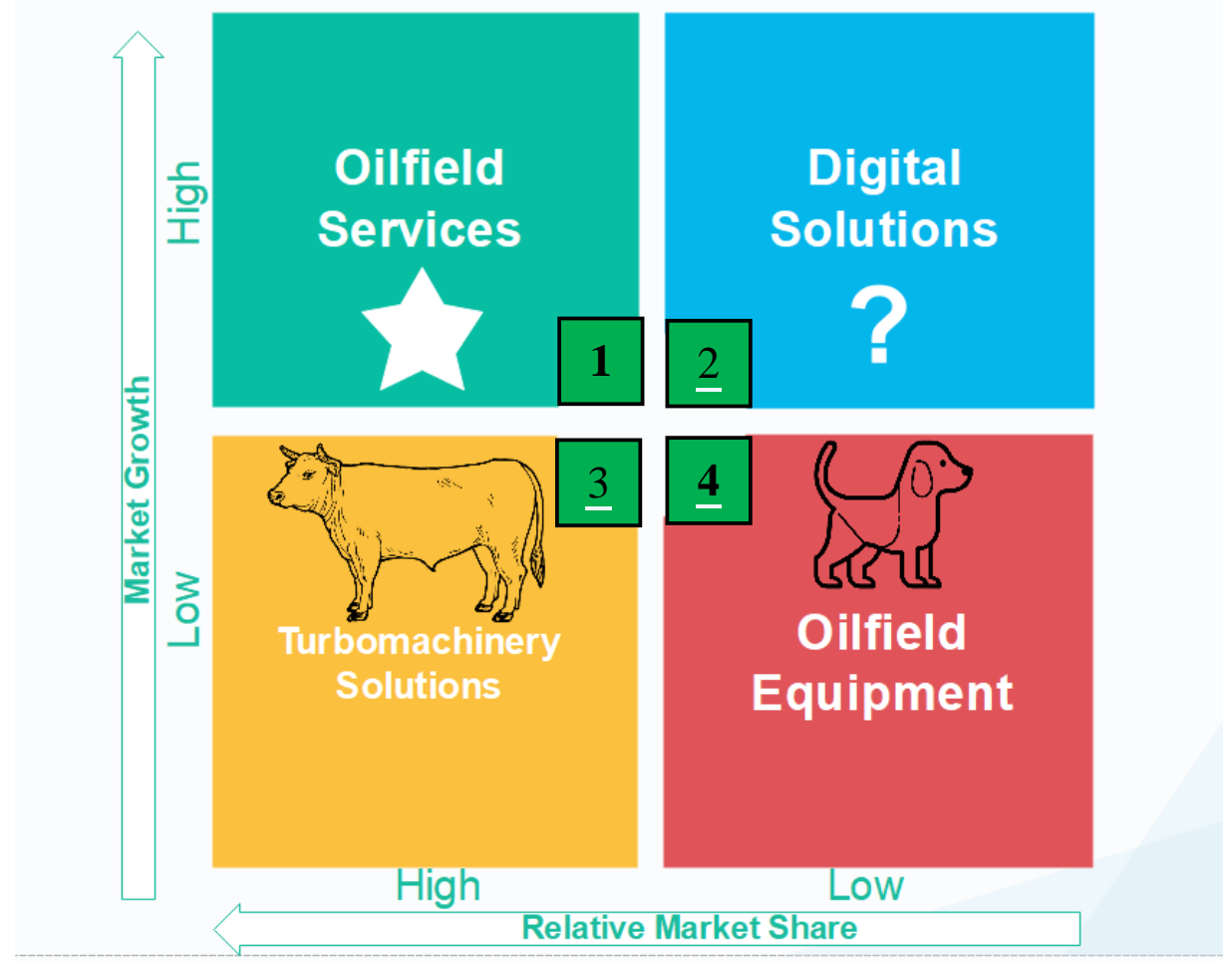

Figure 5. Developed BCG Matrix for BHGE.

investing in maintaining production from mature fields. See Figure 5 for the developed BCG matrix.

\section{STRATEGIC GROWTH ANALYSIS OF GE OIL AND GAS BUSINESS UNIT; A FUTURE PATHWAY}

In this section, some strategic frameworks which the BHGE can develop as an effort for future growth as well as in response to previously identified issues and challenges are presented. The Ansoff Matrix, a corporate strategy framework used for generating strategic directions for organizational growth (Graham, 2008) will be deployed. Based on the following analysis, the differences between each business segment to develop the Ansoff model in Figure 6 have been consciously explored.

Considering grid 3 , there is a need for market development of oilfield equipment and Turbomachinery solution segments since GE oil and gas were faced with difficulty selling their products in the existing market (BHGE Annual Report, 2017). Despite the demand for oilfield equipment, GE's equipment was expensive, bulky, and difficult to install (BHGE Annual Report, 2017). In this case, to better position this business segment in the future, product simplification at a low product and installation cost should be developed. As the company adjusts its products to suit the market demands, the product development strategy under grid 2 is enhanced. So, investment in R\&D activities for the development of new and cheaper products that can eradicate the challenges faced with turbomachinery solutions in the market should be consolidated (Durant, 2019).

For grid 1 (market penetration), building on established strategic capabilities and investment in advanced digital solutions designed which can increase the economies of scale and result in experience curve benefits (Durant, 2019). In the short term, special attention to the current market state due to volatility in crude oil price as a result of the impacts of the COVID 19 (Coronavirus) pandemic should be developed to cushion the economic impact. GE has however been struggling to maintain market shares after acquiring Barker Hughes, hence divestment (grid 4) of BHGE shares has recently been approved to generate funds and streamline a focus on a reduced portfolio (Durant, 2019). Most recently, based on predicted slow gains in operations year 2020 and 2021 after the coronavirus pandemic battered results in the second quarter of 2020, GE announced plans to fully divest from Baker Hughes by selling its remaining 377 million shares over the next three years to settle pay down debt (Blum, 2018; Collins, 2018; Helman, 2020; Beene, 2020). With the oil and gas industry in depression in the second quarter of 2020 , Baker Hughes' revenue went down by $21 \%$ over the previous year and with a loss of $31 \%$ per share. 


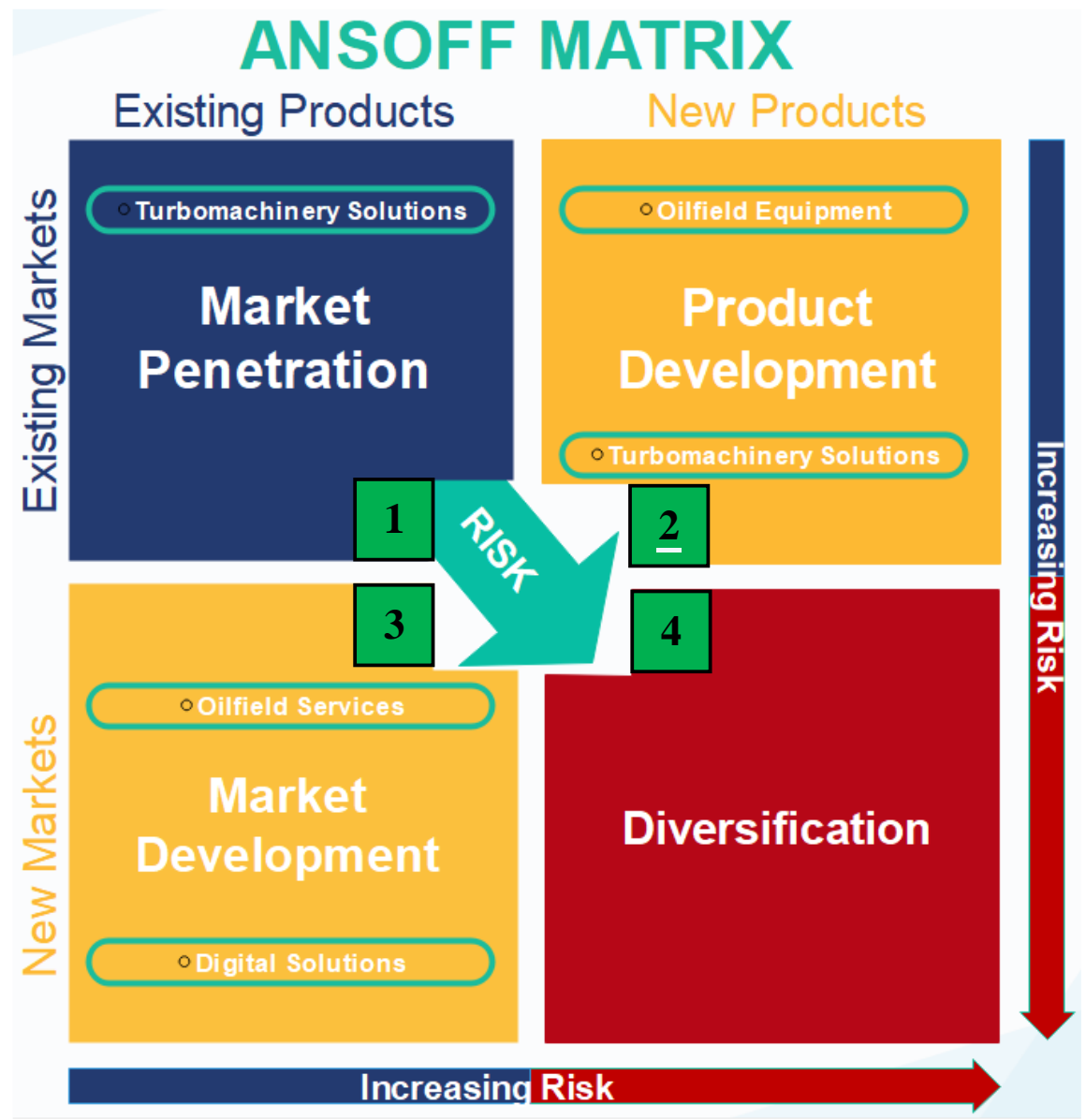

Figure 6. Ansoff Matrix developed for BHGE.

General Electric on the other hand also declared a drop of $38 \%$ in revenue, with a loss of $15 \%$ per share. Hence, it has been a complicated three-year marriage between the two disparate businesses. Aside from achieving a onestop-shop for oilfield equipment and services, the ideology behind the merger in 2017 was to allow General Electric's acquisition to annihilate Baker Hughes underperformance and ensure the expansion of its business structure to withstand competitive rigor from its main rivals: Schlumberger and Halliburton (Blum, 2018; Collins, 2018; Helman, 2020).

\section{CONCLUSION AND RECOMMENDATION}

General Electric renowned for its differentiation strategy with the combined products and service portfolio with Baker Hughes is set to improve the operating margins of General Electric Oil and Gas SBU placing the company as a market leader in innovation, technology, and digitization within the oil and gas industry. It is however evident that the portfolio combination scale has not translated into superior performance. As such, the reality of attaining this scale will be possible if the company keeps track of their strategic goals as well as being sensitive enough to know when to re-strategize plans that will keep them on the competitive edge.

Also, the Integration of GE Oil and Gas SBU with Baker Hughes was hinged upon cost-cutting and quick industry recovery. GE's robust resources and capabilities allow service delivery to its complementary division and SBUs, bringing forth cost-cutting operations. Nevertheless, cost efficiency has not been fully utilized and oil \& gas industry recovery which is supposed to start taking shape have been significantly impacted by the COVID-19 pandemic. One can then say that BHGE's strategy of leveraging on GE's might in digital capabilities and advanced manufacturing to enable them to offer integrated services across upstream, midstream, and downstream, in my opinion, maybe unrelated, and therefore, would only lead to little strategic benefit from the creation of the "fullstream" portfolio. General Electric's intent to achieve global competence in innovation, technology, leadership, and operations optimization without understanding the main differences between the underlying BHGE segments can be preview as being over-estimated. As such, the management should consider the strategic growth options identified in the Ansoff matrix grids developed in this paper 
which, in my opinion, are believed to be value creation drivers to not just the company, their customers, and shareholders but also to humanity instead of the present adoption of complete divestment approach.

Although GE's management is eager to monetize its stake in Baker Hughes given the present condition of the com-pany and considering the conglomerate's need for cash to settle debt, diversification of BHGE will further depress the value creation for its shareholders because "buy high and sell low" approach result to a loss in market share.

We also believe that environmentally, the world is striving to go green due to the immense effects of greenhouse gases which are oftentimes created by companies in the sector of oil and gas. BHGE would benefit greatly from future endeavors of aligning their products and technologies to be more environmentally friendly and lowering their carbon footprint. This initiative if launched in the form of a campaign and aligning itself with organizations such as The United Nations Global Compact (UNGC) may be very fruitful for the company in terms of attracting customers.

\section{CONFLICT OF INTEREST}

The authors declare that they have no conflicts of interest.

\section{REFERENCES}

Beene, R. (2020). GE to divest Baker Hughes stake over three years. Rigzone by Bloomberg. Retrieved from https://www.rigzone.com/news/wire/ge_to_divest_baker_hug hes_stake_over_three_years-29-jul-2020-162861-article/

BHGE Annual Report (2017). Retrieved from https://fintel.io/sfs/us/bhi.

BHGE Annual Report (2018). Retrieved from https://fintel.io/sfs/us/bhi.

Blum J., (2018). GE CEO details plan to divest Baker Hughes after owning it one year, Houston Chronicles, 26 June. Retrieved from https://www.houstonchronicle.com/business/ article/GE-CEO-details-plan-to-divest-Baker-Hughes-after13028746.php

Bucifal, S. (2009). Corporate Strategy Analysis: GE Co. 1981 to present. Crawford School of Economics and Government.

Cairn (2015). Oil and gas exploration and product life cycle. Retrieved

from http://www.cairnenergy.com/index.asp?pageid=554.

Carhcart, S., \& Kania, M. (2017). Baker Hughes and GE Oil \& Gas Complete Combination - Press Release Baker Hughes, a GE company. Retrieved from https://www.bakerhughes.com/ company/news/baker-hughes-and-ge-oil-gas-completecombination-press-release.

Collins, R. (2018). Baker Hughes to go it alone as GE seeks exit from oil sector. Bloomberg, 26 June Retrieved from https://www.bloomberg.com/news/articles/2018-06-26/bakerhughes-to-go-it-alone-as-ge-seeks-exit-from-oil-business.

Colvin, G. (2006). What makes GE great? Fortune, 153(4), 90.

Crocker, B., Jessop, D., \& Morrison, A. (2012). Inbound logistics management: Storage and supply of materials for the modern supply chain, 7th Edition.
Durant, R. (2019). Baker Hughes: GE acquisition will continue to have negative effects long term. Retrieved from https://seekingalpha.com/article/4291305-baker-hughes-geacquisition-will-continue-to-negative-effects-long-term.

Fearne, A., Garcia Martinez, M., \& Dent, B. (2012). Dimensions of sustainable value chains: implications for value chain analysis. Supply Chain Management, 17(6), 575-581.

GE - M\&A Presentation (2016). GE to acquire Baker Hughes M\&A Presentation, Baker Hughes Inc. Retrieved from https://seekingalpha.com/article/4017106-ge-to-acquirebaker-hughes-m-presentation

GE Annual report (2017, 2018). Retrieved from http://www.annualreports.co.uk/Company/general-electric.

Graham, H. (2008). Marketing strategy and competitive positioning. India: Pearson Education India. General Electric. Retrieved from https://www.ge.com/power/about/suppliers/transportationmanagement

Grant, R. M. (1991). The resource-based theory of competitive advantage: implications for strategy formulation. California Management Review, 33(3), 114-135.

Gryta, T., \& Mann, T. (2018). GE Powered the American Century-Then It Burned Out. Wall Street Journal. Retrieved from

https://www.wsj.com/articles/ge-powered-the-americancenturythen-it-burned-out-11544796010.

Helman, C. (2020). GE to sell remaining stake in Baker Hughes over three years. Forbes. Retrieve from https://www.forbes.com/sites/christopherhelman/2020/07/29/g e-to-sell-remaining-stake-in-baker-hughes-over-threeyears/?sh=4e93847d1f29.

Henry, A. (2008). Understanding strategic management. Oxford University Press.

Kenny, G. (2012), Diversification: best practices of the leading companies. Journal of Business Strategy, 33(1), 12-20.

Krajewski, L. J., Malhorta, M. K., \& Ritzman, L. P. (2007). Operations management: Processes and value chains. Upper Saddle River, New Jersey.

Lowder, B. T. (2006). General Electric's quest for global competitive advantage: In search of structural and strategic alignment. SSRN 951103. from: http://dx.doi.org/10.2139/ssrn.951103

Market is Open (2019). The fall of General Electric. Retrieved from https://www.youtube.com/watch?v=F5NumiX-yfl.

Motley Fool (2019), Baker Hughes shows clear signs of improvement heading into 2019. The Motley Fool Publisher. Retrieve from https://www.nasdaq.com/articles/baker-hughesshows-clear-signs-improvement-heading-2019-2019-01-31.

Porter, M. E. (1985). The competitive advantage: Creating and sustaining superior performance. NY: Free Press.

Pratap, A. (2018) Strategic analysis of General Electric' June 14, 2018 and updated: November 15, 2018. Retrieved from https://notesmatic.com/strategic-analysis-of-general-electric/.

Priem, R., \& Butler, J. (2001). Is the resource-based "view" a useful perspective for strategic management research? The Academy of Management Review, 26(1), 22-40.

Reuters (2017). General Electric is making a big investment in oil and gas. Retrieved from https://fortune.com/2017/07/03/gebaker-hughes-merger/.

Reuters (2018). The culture clash behind GE's quick exit from Baker Hughes stake. Retrieved from https://www.reuters.com/article/us-baker-hughes-ge-futureinsight/the-culture-clash-behind-ges-quick-exit-from-bakerhughes-stake-idUSKBN1JM312. 
Reuters (2019). GE begins divestment of Baker Hughes with \$2.7 billion share sale. Retrieved from https://www.reuters.com/article/us-ge-divestiture-bakerhughes-ge-idUSKCN1VX02L.

Sammut-Bonnici, T., \& McGee, J. (2015). Strategic business unit Vol. 12. Strategic management. First published 22 January 2015. Retrieved from https://doi.org/10.1002/ 9781118785317.weom120111.
Stewart, T. A. (2006). Growth as a process. Harvard Business Review, 84(6), 60. 